\title{
AUGUST 2015
}

VOLUME 9 NUMBER 8

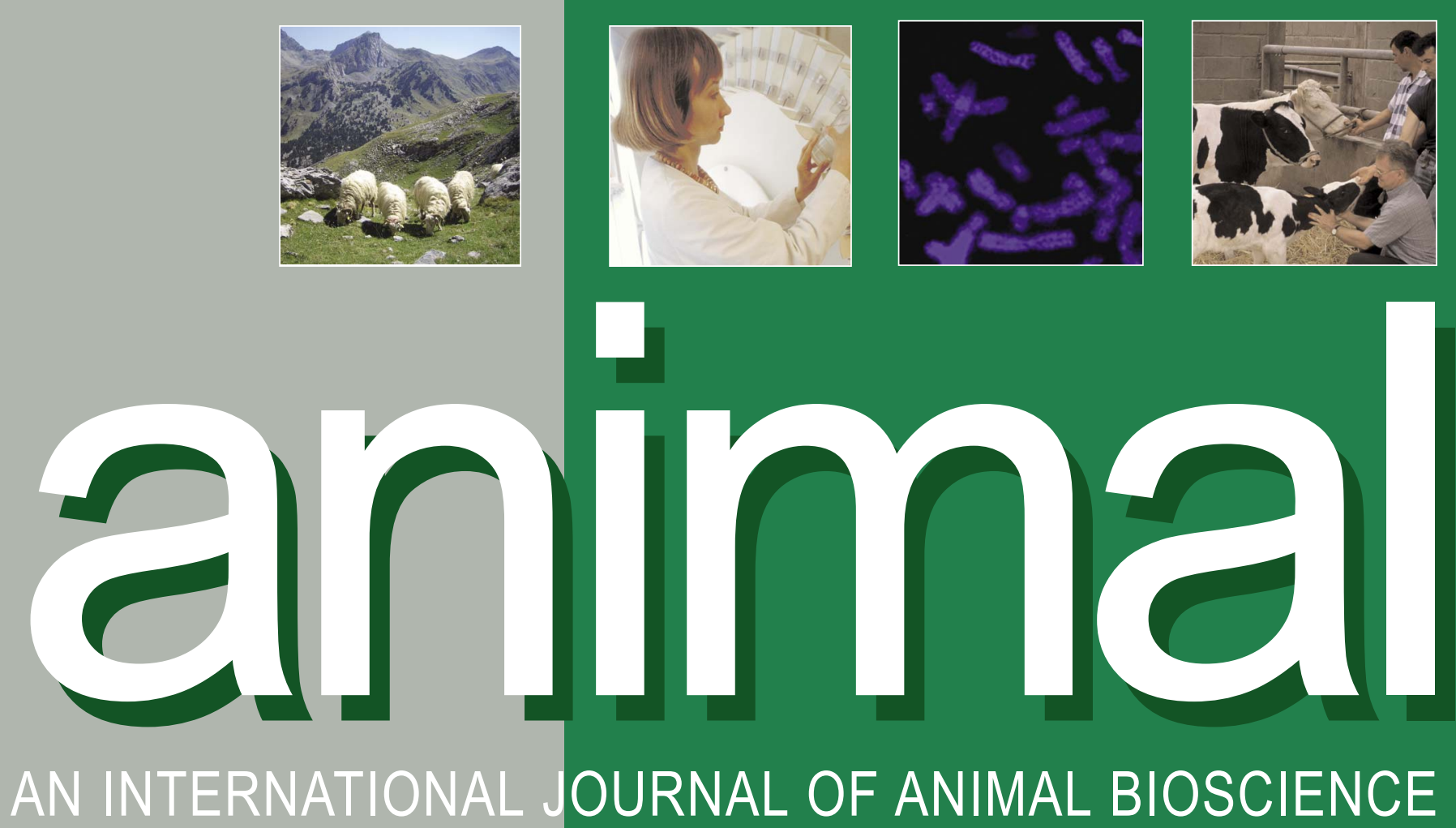




\section{ANIMAL}

\section{Management Board}

N. Scollan (Chair); R. DeWHURST,

H. Simmins, M. STEELE (BSAS);

P. Chemineau, M. Gauly,

A. Rosati (EAAP); N. FRIgGens,

S. INGRAND, J. VAN MILGEN (INRA)

Editor-in-Chief

I. ORTIGUES-MARTY (France)

\section{Editorial Office}

Email: questions@animal-journal.eu

N. Miraux (Editorial Assistant),

B. HILTON and F. FERGUSON

(Technical Editors)

\section{Editorial Board}

\section{Breeding and Genetics.}

Section Editor: S. RODRIGUEZ-ZAS (USA)

Editors: M. CALUS (The Netherlands),

J. CASELLAS (Spain),

T. HASEGAWA (Japan),

A. MALAU-AdUli (Australia),

R. MRODE (UK), M. STEAR (UK),

J. SzYDA (Poland)

\section{Nutrition - Nonruminants.}

Section Editor:

P. Moughan (New Zealand),

Deputy Section Editor:

D. TORRALLARDONA (Spain),

Editors: P. BIKKER (The Netherlands),

W. GERRITS (The Netherlands),

K. HUA (Germany), D. JóZEFIAK (Poland),

J. MatTE (Canada) J. MurRaY (UK),

R. RAVINDRAN (New Zealand),

B. Silva (Brazil), R. Sulabo

(Philippines), J.-D. Van DeR Klis (The

Netherlands), J. VAN MILGEN (France),

B. Williams (Australia)

\section{Nutrition - Ruminants.}

Section Editor:

K. SHINGFIELD (UK),

Editors: H. ARCHIMEDE (France),

J. Brameld (UK), J. De Boever

(Belgium), R. DEWHURST (UK), L. Doepel

(Canada), V. FIEVEZ (Belgium),

R. Gervals (Canada), S. Huws (UK)

D. McNeILl (Australia), C. McSwEENEY

(Australia), J. NEWBOLD

(The Netherlands), D. PACHECO

(New Zealand), M. J. RANILLA (Spain),

T. SCHONEWILLE (The Netherlands),

K.-H. SÛDEKUM (Germany)

Physiology and Functional Biology of Systems.

Section Editor:

M. VesteRGAARD (Denmark)

Deputy Section Editor:

W. Rauw (Spain),

Editors: G. DAHL (USA), G. HAUSMAN

(USA), R. HILL (Australia), K. HoltenIUS

(Sweden), D. KENNY (Ireland), P. LACASSE

(Canada), L. MAERTENS (Belgium),

P. MERMILLOD (France), P. MozdZIAK

(USA), R. RAMACHANDRAN (USA),

J. SharP (Australia), G. VATZIAS (Greece),

P. Wynn (Australia)

Behaviour, Welfare and Health.

Section Editor: M. COCKRAM (Canada),

Deputy Section Editor: B. L. NIELSEN

(France), Editors: N. BAREILLE (France),

A. BoIsSY (France), S. EdWARDS (UK),

U. EMANUELSON (Sweden),

E. MERLOT (France),

M. SUTHERLAND (New Zealand),

E. Von BORELL (Germany)

E. WATTRANG (Sweden)

Farming Systems and Environment.

Section Editor: A. BERNUES (Spain),

Deputy Section Editor: M. GAULY

(Germany), Editors: A. ADESOGAN

(USA), A. DUNCAN (Ethiopia),

I. Halachmi (Israel), N. MiRAGlia (Italy),

B. NICKS (Belgium), S. OOsting (The

Netherlands), H. PouLSEN (Denmark),

J. T. SORENSEN (Denmark)

Product Quality, Human Health and Well-Being.

Section Editor: A. BALDI (Italy),

Deputy Section Editor: B. LEBRET

(France)

Editors: G. BEE (Switzerland), M. CAMPO (Spain), I. Givens (UK), C. RYMER (UK)

Statistical Editor: C. CIERCO (France)

EAAP invited reviews Editor:

H.M. NIELSEN (Norway)

Aims and Scope of the journal

Animal attracts the best research in animal biology and animal systems from across the spectrum of the agricultural, biomedical, and environmental sciences. It is the central element in an exciting collaboration between the British Society of Animal Science (BSAS), the Institut National de la Recherche Agronomique (INRA) and the European Association of Animal Production (EAAP) and represents a merging of the three scientific journals: Animal Science; Animal Research; Reproduction, Nutrition, Development. Animal publishes original cutting-edge research, 'hot' topics and horizon-scanning reviews on animal-related aspects of the life sciences at the molecular, cellular, organ, whole animal and production system levels.

The main subject areas include: breeding and genetics; nutrition; physiology and functional biology of systems; behaviour, welfare and health; farming systems, environmental impact and climate change; product quality, human health and well-being. Animal models and papers dealing with the integration of research between these topics and their impact on the environment and people are particularly welcome. The detailed scope of the journal can be found at www.animal-journal.eu/scope.htm

\section{Submission of Manuscripts}

All manuscripts must be submitted online via the website: http://www.editorial manager.com/animal/

Please consult the full instructions for authors at: www.animal-journal.eu/ instructions_to_authors.htm

\section{Subscriptions}

Animal (ISSN 1751-7311) is published monthly. The subscription price for institutions of Volume 9 (2015) which includes electronic access and delivery by air is $£ 967, € 1185$ (US $\$ 1891$ in the

USA, Canada and Mexico); the electronic only price for institutions is $£ 743$, €967 (US \$1492 in the USA, Canada and Mexico). Single parts are $£ 89, € 109$ (US $\$ 173$ in the USA, Canada and Mexico), plus postage. Orders, which must be accompanied by payment, may be sent to a bookseller, subscription agent or direct to the publisher: Cambridge University Press, Journals Fulfillment Department, University Printing House, Shaftesbury Road, Cambridge CB2 8BS, UK; or in the USA, Canada and Mexico: Cambridge University Press, Journals Fulfillment Department, 100 Brook Hill Drive, West Nuack, New York, 10994-2133. EU subscribers (outside the UK) who are not registered for VAT should add VAT at their country's rate. VAT registered subscribers should provide their VAT registration number. Japanese prices for institutions are available from Kinokuniya Company Ltd, P. O. Box 55 Chitose, Tokyo 156, Japan.

Copies of the journal for subscribers in the USA, Canada and Mexico are sent by air to New York to arrive with minimum delay.

Periodicals postage paid at New York, NY, and at additional mailing offices. Postmaster: send address changes in the USA Canada and Mexico to: Animal, Cambridge University Press, 100 Brook Hill Drive, West Nyack, New York 10994-2133. Claims for missing issues should be made immediately on receipt of the subsequent issue.

\section{Advertising}

Advertising queries for all parts of the world except the USA, Canada and Mexico to ad_sales@cambridge.org

Address enquiries in the USA, Mexico and Canada only to:

USAdSales@cambridge.org

\section{Copying}

This journal is registered with the Copyright Clearance Center, 222 Rosewood Drive, Danvers, MA 01923, USA (www.copyright.com). Organizations in the USA who are also registered with CCC may therefore copy material (beyond the limits permitted by sections 107 and 108 of US copyright law) subject to payment to CCC. This consent does not extend to multiple copying for promotional or commercial purposes.

ISI Tear Sheet Service, 3501 Market Street, Philadelphia, PA 19104, USA is authorized to supply single copies of separate articles for private use only.

Organizations authorized by the Copyright Licensing Agency may also copy material subject to the usual conditions. For all other use, permission should be sought from Cambridge or the American Branch of Cambridge University Press.

\section{Internet Access}

This journal is included in the Cambridge Journals Online Service which can be found at www.journals.cambridge.org Front cover images

Mountain scene photograph courtesy of Julian Casasús. Other images @ C INRA Picture Library.

This journal issue has been printed on FSC-certified paper and cover board. FSC is an independent, non-governmental, not-for-profit organization established to promote the responsible management of the World's forests. Please see www.fsc.org for information.

Printed in the UK by Bell \& Bain Ltd., Glasgow.

(C) Animal Consortium 2015 


\section{animal}

\section{AN INTERNATIONAL JOURNAL OF ANIMAL BIOSCIENCE}
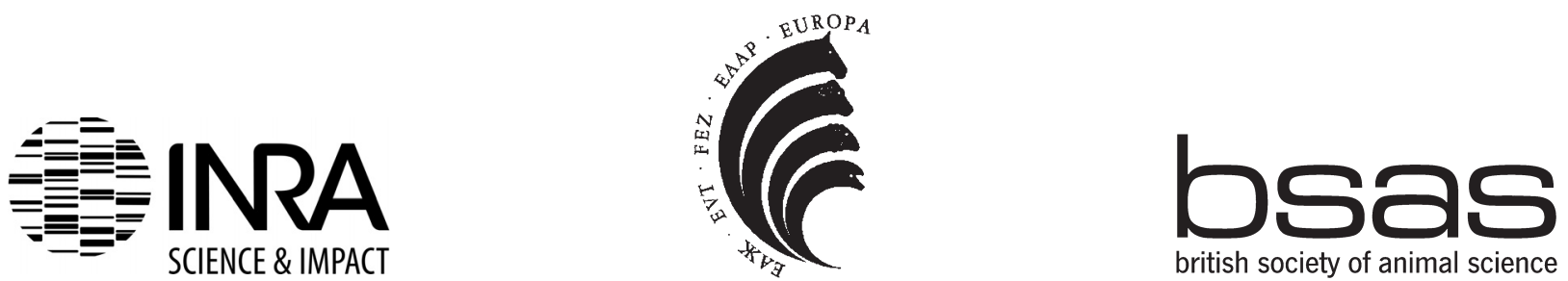


\section{CAMBRIDGE JOURNALS}

\section{Leading titles \\ across multiple}

disciplines
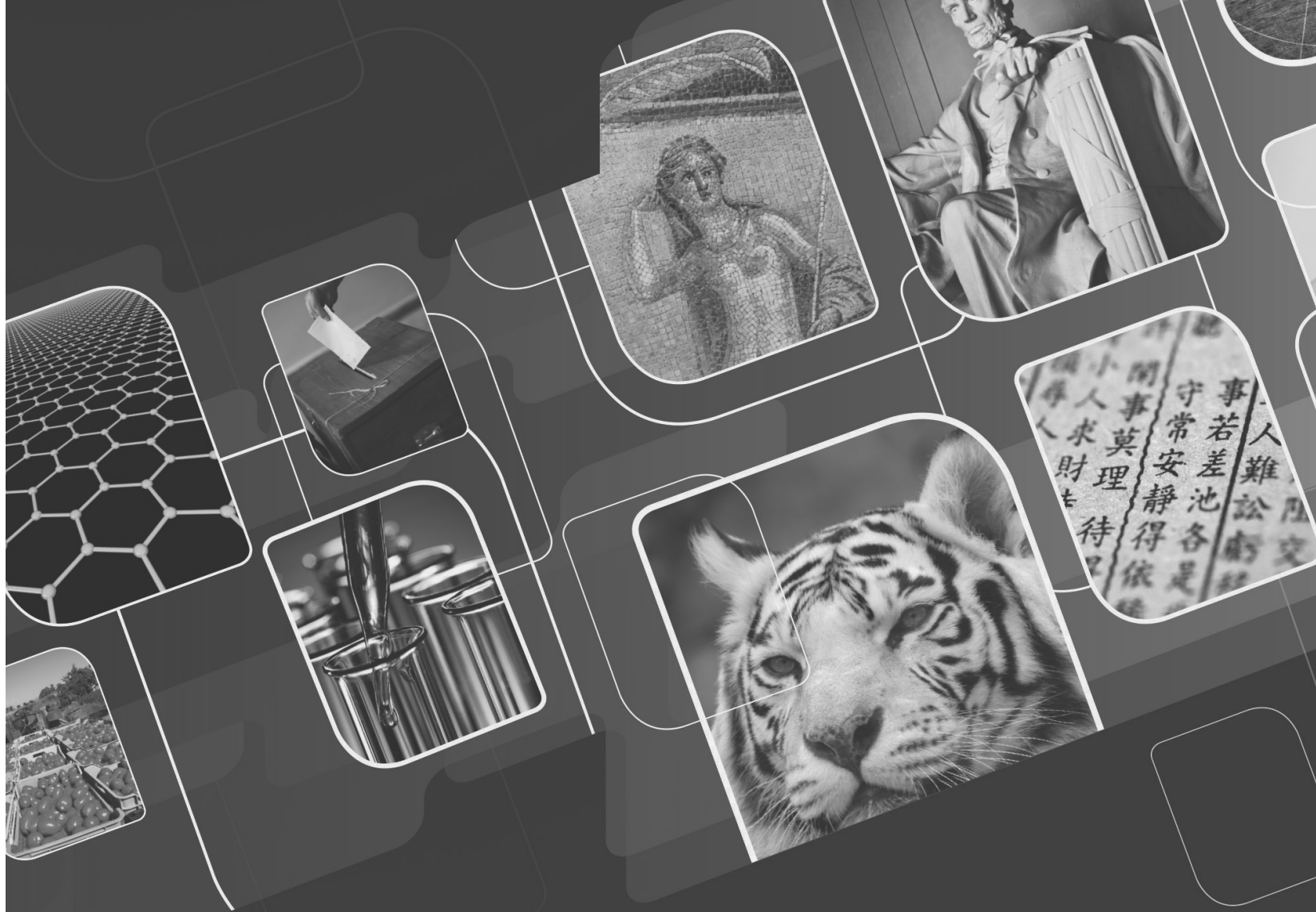

Access today at:

journals.cambridge.org 